\title{
SOIL HETEROGENEITY REFLECTED IN BIOGEOGRAPHY OF BEECH FORESTS IN THE BORDERLAND BETWEEN THE BOHEMIAN MASSIF AND THE OUTER WESTERN CARPATHIANS
}

\author{
PAVEL SAMEC ${ }^{1 *}$, ALEŠ KUČERA², KLEMENT REJŠEK ${ }^{2}$
}

${ }^{1}$ Department of Geoinformatics, Faculty of Science, Palacký University Olomouc, 17. listopadu 50, 77900 Olomouc, Czech Republic; e-mail: psamec@post.cz

${ }^{2}$ Faculty of Forestry and Wood Technology, Mendel University, Zemědělská 3, 61300 Brno, Czech Republic

* Author for correspondence

\begin{abstract}
Samec P., Kučera A., Rejšek K.: Soil heterogeneity reflected in biogeography of beech forests in the borderland between the Bohemian Massif and the Outer Western Carpathians. Ekológia (Bratislava), Vol. 33, No. 4, p. p. 321-343, 2014.

Soil environment characteristics naturally affect the biogeographical classification of forests in central Europe. However, even on the same localities, different systems of vegetation classification describe the forest types according to the naturally dominant tree species with different accuracy. A set of 20 representative natural beech stands in the borderland between the Bohemian Massif (Hercynian biogeographical subprovince) and the Outer Western Carpathians (Westcarpathian subprovince) was selected in order to compare textural, hydrostatic, physico-chemical and chemical properties of soils between the included geomorphological regions, bioregions and biotopes. Differences in the soils of the surveyed beech stands were mainly due to volume weight and specific weight, maximum capillary capacity (MCC), porosity, base saturation (BS), total soil nitrogen $\left(\mathrm{N}_{t}\right)$ and fulvic acids. Specifics in the relations between these soil characteristics indicated that transient trans-Hercynian beech forests developed in the borderland between the two compared subprovinces. Soils of the investigated Hercynian beech forests were generally characterized by lower $B S$ and lower $\mathrm{N}_{\mathrm{t}}$. Soils of the trans-Hercynian beech forests were more similar to the Carpathian beech forest soils than soils in the other Hercynian beech forests. Soils of the trans-Hercynian and Carpathian beech forests showed similarly higher $B S$, deeper occurrence of humic substances, lower specific weight and also higher MCC. Higher content of humic substances as well as $M C C$ indicated an equal effect on forest ecology, which may contribute to more accurate classification of forests.
\end{abstract}

Key words: European beech, biogeographical subprovince, fulvic acids, soil maximum capillary capacity.

\section{Introduction}

Natural forest conenoses, from the Atlantic to sub-continental Europe, are composed of a mosaic of regional forest types. However, their classification is often different, even for the 
same dominant tree species (Chytrý, 2012). Natural causes of this diversification arise from the interactions of a plant community with its environment (Zinke, 1962).

The relationship between plant communities and their environment is reflected in the development of unrepeatable ecological units. Peculiar interactions exist between root systems of plants and soil environment (Godefroid et al., 2005; van der Poel, 1976).

In oak-hornbeam forests, ecosystems composed of regional populations have been distinguished, while in beech stands within the Czech Republic (CR), ecological variability has so far been mapped only with regard to site carrying capacity, but not in relation to their geographical location. Even on the small territory of the CR, the natural oak-hornbeam conenoses still retain the character from the individual biogeographical sub-provinces present (Hercynian Melampyro nemorosi-Carpinetum; Carpathian Carici pilosae-Carpinetum; Polonian Tilio cordatae-Carpinetum; Pannonian Primulo veris-Carpinetum) and even develop sub-endemic adaptations according to the local unique ecotope (south-bohemian StellarioTilietum and bog Tilio-Betuletum) (Knollová, Chytrý, 2004).

The classification of European forest types (EFT) divides European beech forests into Atlantic, Central European and sub-mediterranean communities (Barbati et al., 2007). Central Europe includes nine biogeographical sub-provinces in total. Contact of the Hercynian and Westcarpathian biogeographical sub-provinces on the territory of the CR is accompanied by occurrence of several non-representative zones where Carpathian, subcontinental and Central-European geo-elements mingle (Culek, 1996). However, the European classification of natural biotopes does not presume the potential occurrence of several regional types of beech forests on the territory of the CR (cf. Chytrý et al., 2001), although four biogeographical sub provinces are found on the territory of the CR, three on the territory of Austria and two on the territory of Poland.

Beech forests are the dominant conenoses of these parts of Europe (Pott, 2000). Although beech (Fagus sylvatica L.) naturally tends to form monocoenoses, the communities that it creates show locally different dynamics (Christensen et al., 2005; Gömöry et al., 1997; Seynave et al., 2008). Thanks to the adaptability of beech to the soil-forming substrate properties; beech stands display unequal competitiveness in different parts of their range and on different sub-soils (Ngao et al., 2005; Davi et al., 2005; Diaci, Rozenbergar, 2003; Sugiero et al., 2009).

Competitiveness of beech is mainly based on its ability to make use of several survival strategies (Casper, Jackson, 1997; Craine, 2007; Schmid, 2002). The character of interactions between the root system of beech and the soil environment is usually assessed on the basis of humic substance chemistry (Finzi et al., 1998). On one hand, soil humus reduces soil wet bulk density $\left(D_{w}\right)$ while on the other hand, $D_{w}$ is an important indicator of differentiation in soil-forming processes, porosity (P), aeration (A) and physiological availability of water (White, 1987).

Relations between soil humus and hydrostatic properties of soil are potentially reflected in the ecology of the whole community (Tan, 2003). If the development of some communities specifically depends on soil conditions, then the variability of these conditions will implicate also the variability of these communities. When such variability is also of biogeographic significance, the locally unique soil conditions will be one of the important factors for deter- 
mination of the biogeographical units as well. Soil conditions affect the altitudinal distribution of plant species (Gégout, Križová, 2003), the size of their arels and areals (Gaston, Spicer, 2004) and potentially they can also influence the changes of competitiveness of the natural communities on the borders between biogeographical subprovinces (Horáček et al., 2011).

Relations between the external growing environment, ecosystem productivity, litter production and soil humus production effectiveness play significant roles in variability of beech forest ecology. Lower interception of precipitation, lower anion leaching and lower leaching of organic acids into subsoil jointly decrease the fluctuations of soil internal processes in broadleaved stands, hence the self-regulation mechanisms depending on the sole presence of a specific tree species can manifest themselves to a greater extent (Allison, 1973).

Soil humus is the basic factor implicating also the total water-holding capacity of soil (Wheeler, Ward, 1998). The status of soil humus markedly differentiates the ecology of beech stands on acidic and trophic sites (Patzel, Ponge, 2001).

Since the borderline between the Bohemian Massif with its characteristic acidic soils and the Outer Western Carpathians, typically with mesotrophic and trophic soils (Purdon et al., 2004), plays an important role in the studies of forest ecology on the territory of the Czech Republic; in the present study we attempted to analyze the relations of the hydrostatic and humic properties of soils in natural beech forests along this biogeographically important border.

\section{Material and methods}

\section{The aim of the work}

The objective of our study was to determine whether soil characteristics can indicate the conditions leading to development of regional types of natural beech forests. Soil parameters and soil units were chosen as characteristics of soil conditions (internal components of the growing environment) in beech forests. The features of beech forest biogeography were described with the help of geographical division of the forest type occurrence (aspects of the external environment). The geographical divisions of the beech forest occurrence included both regional geography of beech forests and typological classification of beech forest biotopes (Kaplan, 2012). Geomorphological and biogeographical division of beech forests are linked to the analysis of regional specifics of ecosystem occurrence in general (Gaston, Spicer, 2004). Classification of natural biotopes within the CR is generally linked to the typological classification of forests (Barbati et al., 2007). Significance of the regionally-geographical classification of beech forests for differentiation of soil conditions was assessed with the use of geomorphological regions (Demek, 1987) and bioregions (Culek, 1996). Biotope classification was performed according to Chytrý et al., (2001). Thanks to these comparisons, it was possible to determine whether there are traceable regional differences between beech forests, or whether the influences of vertical and edaphic division of biotopes are of dominant influence.

\section{Selection of beech forests}

The basic set of data on soil properties was obtained from sampled soil pits in selected specially-protected natural beech forests within the borderland between the Bohemian Massif and the Western Carpathians in the Czech Republic, both in the Hercynian and the West Carpathian subprovince in 2005-2008. The localities for sample collection were chosen to cover the three typical geomorphological regions of beech forest occurrence along the eastern edge of the Bohemian Massif and the three typical geomorphological regions of the Outer Western Carpathians. Geomorphological division of the CR was taken from the GIS layer by Voženílek (2000). Individual specially-protected areas were selected from a set of areas investigated during monitoring of management strategies applicability in areas with special protection status on the territory of the CR (Simon, 2004). Special protection status was understood as simultaneous occurrence of a forest geobiocoenological reservation and a Site of Community Importance according to Natura 2000 network (Simon, 2010). 
The chosen geomorphological units comprise 32 bioregions. We selected 9 of them (representing $10 \%$ of the CR area) in which the potential share of beech stands exceeds $70 \%$ of the natural area of forests (Table 1 ). The potential occurrence of beech forests was derived from the overall representation of oak-beech, beech, fir-beech and spruce-fir-beech vegetation zone reduced to the share of hydrically normal and periodically waterlogged sites (Ellenberg, 1996). Data for this analysis were taken from Culek (1996). The selection of bioregions from the Hercynian biogeographical subprovince in our study corresponds to the Bohemian Massif, selection of bioregions from the West Carpathian biogeographical subprovince corresponds to the Outer Western Carpathians. Five bioregions were chosen from the Hercynian biogeographical subprovince and four from the Outer Western Carpathians; however, our selection from the Bohemian Massif included only 8 specially-protected beech forests while from the Outer Western Carpathians it included 12 beech forest localities (Table 2). According to EFT classification, the selected beech forests correspond to the Central European submountainous beech forests (6.6.4) or the Central European mountainous beech forests (6.7.2). They cover all four beech forest biotopes determined on the territory of the CR (Kučera et al., 2011): herb-rich beech forests (L5.1), montane sycamore-beech forests (L5.2), limestone beech forests (L5.3) and acidophilous beech forests (L5.4).

\section{Soil data}

In each of the selected beech forest, field sampling was situated in a representative square with the area of 1 ha (Simon, 2003). One deep soil pit was excavated in each square, the exposed soil unit was identified according to WRB-ISSS-ISRIC classification (Driessen et al., 2001) and soil samples were collected from each genetic horizon. Soil humus forms were described with the use of the taxonomic system by Green et al. (1993).

Laboratory analyses of the soil samples focused on assessing the following parameters: (1) content of physical clay (PC) using pipette analysis (USDA-NRSC, 1996); (2) physico-chemical properties $\mathrm{pH}$ active $\left(\mathrm{pH} / \mathrm{H}_{2} \mathrm{O}\right)$ and potential $\left(\mathrm{pH} / \mathrm{CaCl}_{2}\right)$ in water and $0.01 \mathrm{M} \mathrm{CaCl}_{2}$, respectively, acidometrically from the suspension with 1:2.5 ratio (w:v) (ISO 10390), cation exchange capacity (CEC) expressed as the sum of concentrations of all extracted exchangeable cations (White, 1987), base cation content $(B C C)$ and base saturation (BS), where $B C C\left(\mathrm{Ca}^{2+}, \mathrm{Mg}^{2+}, \mathrm{K}^{+}\right.$ and $\mathrm{Na}^{+}$) were extracted with Mehlich 3 solution (Mehlich, 1984) and acid cations $\left(\mathrm{H}^{+}\right)$were determined by double measurement of pH (Adams, Evans, 1990); (3) content of humic substances based on the content of organic carbon $\left(\mathrm{C}_{\mathrm{ox}}\right)$ by oxidation in chromium-sulphuric acid (Walkey, Black, 1934), total Kjeldahl nitrogen in soil (Nt) (Houba et al., 1989) and carbon fractions in lightly-bound fulvic acids $\left(\mathrm{C}_{\mathrm{FA}}\right)$, humic acids $\left(\mathrm{C}_{\mathrm{HA}}\right)$ and in total humic substances (THS) by spectrophotometry of sodium pyrophosphate solution (Kononova, Bělčikova, 1961); (4) hydrostatic properties by quantitative analysis of samples in metal core cylinders $D_{\mathrm{w}}$, bulk density $\left(D_{\mathrm{d}}\right)$, specific density $\left(D_{\mathrm{s}}\right), P, A$, maximum capillary capacity $(M C C)$, maximum air capacity $(M A C)$, relative capillary moisture $(R C M)$ and relative pore saturation (RPS) (Vavř́ćck et al., 2006). The characteristic values of soil properties of the beech stands studied were determined via arithmetic averages and 95\% standard deviations (SD).

\section{Statistical analyses}

The obtained data were divided into categorizing variables including geographical division of the beech stands within the survey and into explained variables of individual soil characteristics. The objective of statistical data analysis was to determine the relations between the individual soil characteristics as well as to assess the extent of differences between the units of their geographical division. Relations between the individual soil characteristics were investigated with multivariate exploratory data analysis. The extent of differences in geographical division of beech stands was estimated by linear discriminate analysis (DA).

Multivariate exploratory analysis of the relations between the individual soil characteristics was performed with application of cluster analysis (CLU) and factor analysis (FA). Normal distribution of the compared soil characteristics was examined by a test of skewness and kurtosis with the critical value of 1.96 (Zar, 1994). CLU was performed with a robust single linkage $z$-transformation of data with Euclidean distances (Rand, 1971). To determine the effects of data division on the mutual relations between the individual soil characteristics, FA was performed with normalized as well as with the original data. Data normalization was carried out by Box-Cox transformation (Box, Cox, 1964). For the FA, the variables with weights exceeding the factor loading of $P>0.70$ were preferred. The number of the component factors included was limited to those that jointly covered $>50 \%$ of the data variability. Intersection of the FA and CLU results produced a selection of the statistically close soil characteristics for subsequent analysis of their differences between the units of beech forest geographical division. 

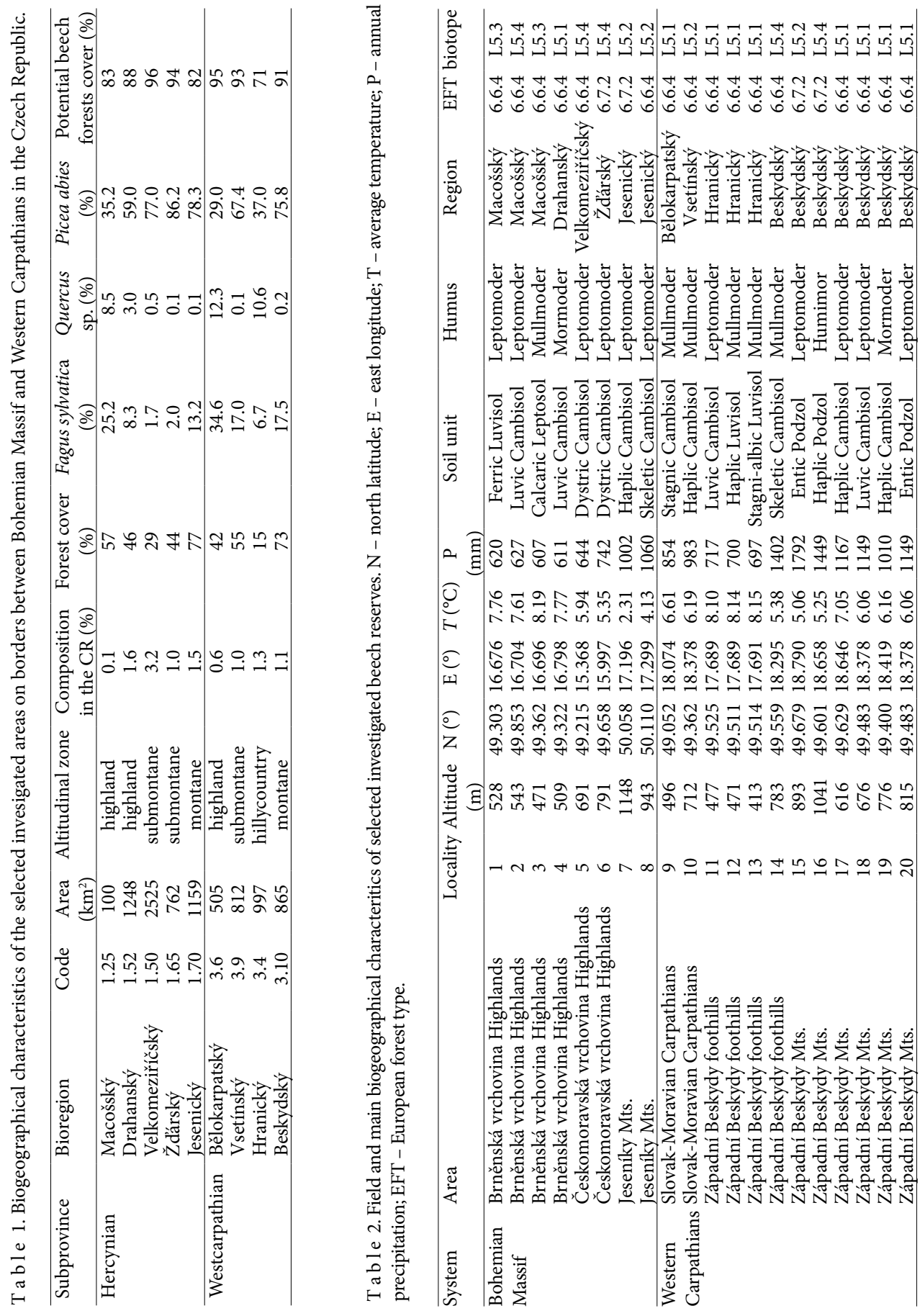
To assess the biogeographical conditionality of the differences in the selected soil properties, DA of the geomorphological regions, bioregions and biotopes were compared. The aim of the DA of geographical divisions of soil variables was to determine whether the regional conditions in beech stands are more affected by regional division or by biotope classification (Verdú et al., 2003). Soil conditions were described with categorical variables of soil horizons and soil types. Soil horizons from the individual soil pits were merged into top-soil, eluvial, diagnostic and sub-soil layers. DA of the selected statistically close soil characteristics in the merged soil horizons allowed us to assess the differences caused by stratigraphy of soil bodies. DA of the horizons of repeating soil units allowed us to assess, which differences in division of the soil properties are caused by soil types. Differences in soil characteristics related to vertical sequence of soil horizons or between soil types could potentially distort the desired information on the links between soil properties and biogeography of beech forests. Re-classification of the compared soil characteristics in beech stands with DA enabled revision of their original geographical classification and a suggestion of soil-dependent division (Qian, Ricklefs, 2004).

\section{Results}

\section{Site analysis}

In the selection of natural beech forests, Central-European sub-montane beech forests (6.6.4) clearly prevailed over Central-European montane beech forests (6.7.2). Share of 6.6.4 ecosystems in the selected stands of interest was $80 \%, 6.7 .2$ ecosystems represented $20 \%$. This proportion reflected the preferred geomorphological regions for the field survey as well as the preferences in the selection of stands suitable for monitoring of management strategies in areas with special protection status. $40 \%$ of the stands of interest were selected within the Bohemian Massif territory, the remaining 60\% were found in the Outer Western Carpathians.

The 6.6.4 ecosystems were represented by all four biotopes of beech forests known from the territory of the CR. Herb-rich beech forests formed 56\%, acidophilous beech forests $19 \%$ and montane sycamore-beech forests together with limestone beech forests covered $25 \%$ of the Central-European sub-montane beech forests area. Within the Central-European mountainous beech forests, only acidophilous beech forests and montane sycamore-beech forests were found. Together in the selection of all beech forests, the biotopes of herb-rich beech forests represent $45 \%$, montane sycamore-beech forests $20 \%$, limestone beech forests $10 \%$ and acidophilous beech forests $25 \%$.

Dominance of Central-European sub-montane beech forests over Central-European montane beech forests also affected the total numbers of the soil units found. In 6.6.4 ecosystems, 10 different soil units were exposed in total, while in 6.7.2 ecosystems, 4 soil units were exposed in total. Three soil units appeared in both EFT groups. Haplic Cambisols and Luvic Cambisols are codominant within the selected beech forests, Skeletic Cambisols are subdominant. Other soil units, jointly representing $50 \%$ of the soil profiles examined, were each found only once. However, within the selected forests, higher occurrence of gleyic soil units was evident in lower locations and higher occurrence of Podzols in higher locations. In the investigated acidophilous beech forests, mostly Dystric Cambisols and Haplic Podzols were found, but Luvic and Skeletic Cambisols appeared as well. In the herb-rich beech forests within this study, mainly Haplic Cambisols and Luvic Cambisols were found; Entic Podzols, Haplic Luvisols and Stagnic soils also occurred. Entic Podzols and Haplic Cambisols were also found in montane sycamore-beech forests. 

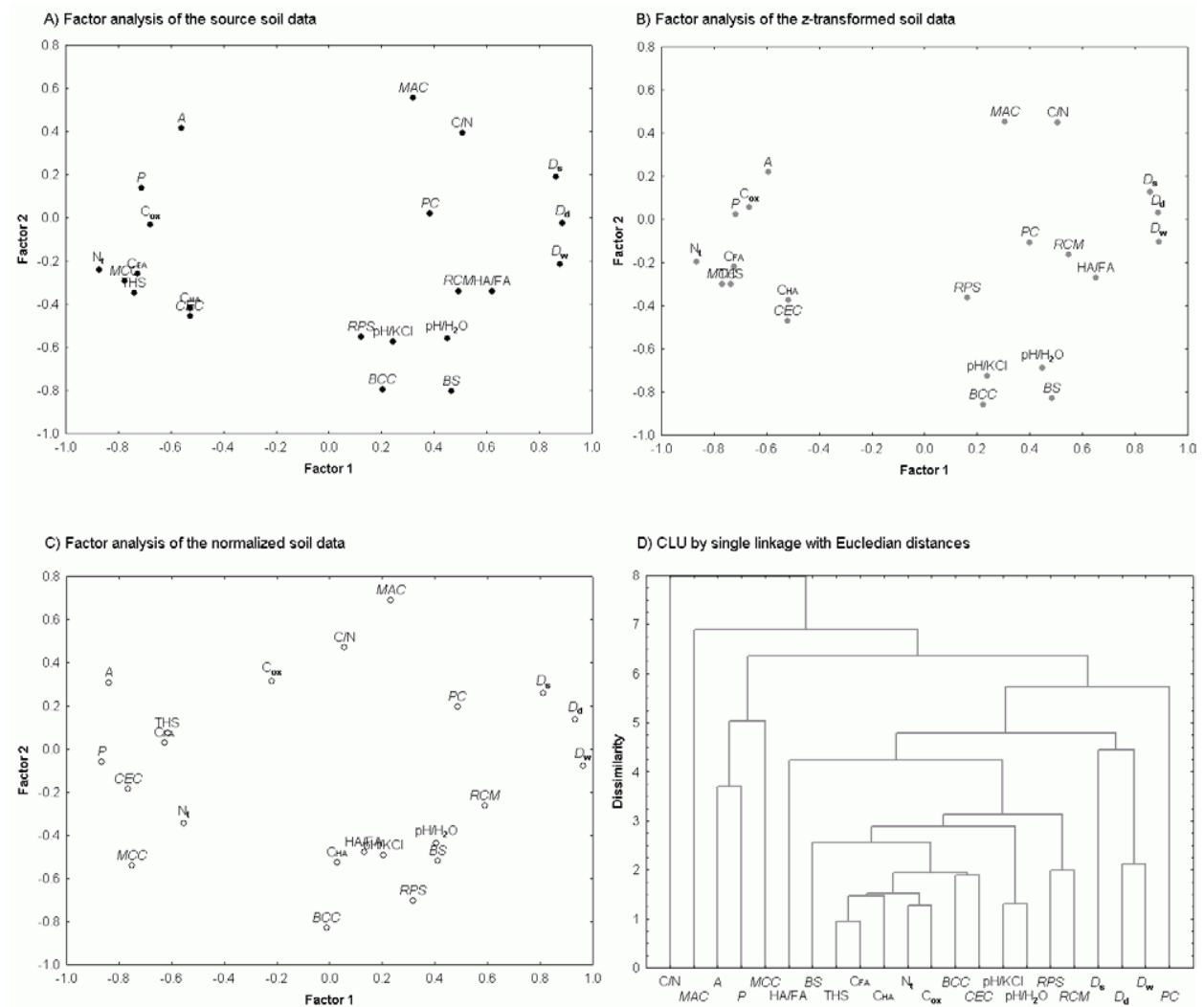

D) CLU by single linkage with Eucledian distances
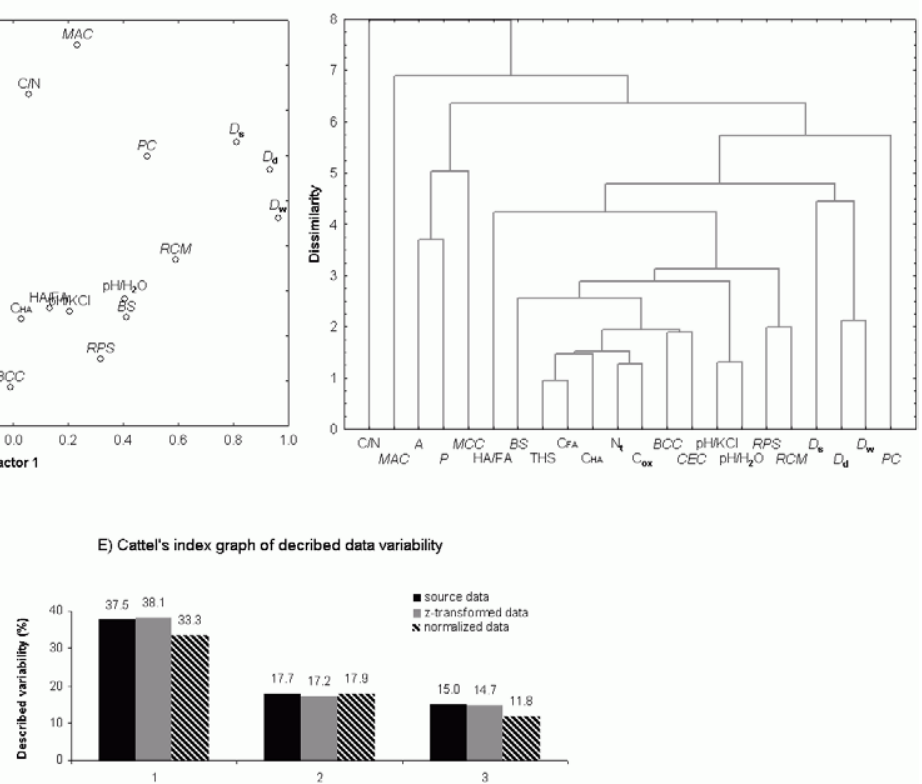

Fig. 1. Multivariate statistics at source, $\mathrm{z}$-transformed and normalized data.

Moder forms of humus were mostly present in the studied beech forests. The most frequent was Leptomoder, found in six soil units in total. Lower frequency showed Mullmoder, found in five soil units. Leptomoder appeared relatively more often in the Hercynian regions, Mullmoder was more frequent in Carpathian regions. Leptomoder prevailed in Cambisols, while Mullmoder apparently evenly occurred in Skeletic, Haplic and Stagnic Cambisols and in Luvisols. It was found both in neutral to alkaline soils and in stagnic soils. Both intermediate forms Mullmoder and Mormoder in some cases substituted for Leptomoder in Haplic 
Cambisols, Luvic Cambisols and Skeletic Cambisols. Mormoder and Humimor were strongly linked to specific soil types in the studied stands. Humimor was found exclusively in Podzols.

\section{Soil properties selection}

The character of multivariate analyses of relations between soil properties of all monitored objects seemed unaffected by the departure of the distribution of individual characteristics from normality, however, it was affected by natural relations between hydrostatic and physico-chemical properties. The way of transformation of soil properties slightly affected the level of variability expressed by the component factors found, but it also affected equivalence of the links between CLU and FA. The first two component factors of source data and $\mathrm{z}$ transformed values included over $55 \%$ of the overall variability of relations. However, the first two component factors of the normalized values included only $51 \%$ of the overall variability of relations. In the source and the normalized data, factor loadings marked the similarities of features of individual properties already within the first two most influential factors. In the $\mathrm{z}$-transformed data, factor loadings marked the similarities of features of the individual properties in three factors in total. Statistical links between the hydrostatic and physicochemical soil properties were arranged into a cluster $D_{w^{\prime}} D_{\mathrm{d}}$ and $D_{\mathrm{s}}$, cluster MCC, $P$ and $A$ and a cluster of sorption characteristics, $\mathrm{pH}$, chemical composition of humus, RPS and RCM. The whole cluster of physico-chemical and humus-related properties seems to be replaceable by the HA/FA ratio. In contrast to that, the content of clay, $\mathrm{C} / \mathrm{N}$ ratio or MAC does not have clear relations to the other soil characteristics (Fig. 1).

FA confirmed the significance of $D_{w}, D_{d}, D_{s}, M C C$ and $P$ for the state of sorption complex and humus composition. FA of the normalized values indicated that at normal distribution, hydrostatic properties can be linked more closely to CEC and BCC than to the properties of humus substances. The transformations of values used showed that at normal distribution, influence of $A$ and RPS on the other soil characteristics is also evident. Although CLU indicated that RPS together with RCM displayed closer relations to sorption and humus properties than to volume weight, soil aeration showed no connection to the physico-chemical properties. Nevertheless, links of THS, $\mathrm{C}_{\mathrm{FA}}$ and $\mathrm{N}_{\mathrm{t}}$ to sorption and hydrostatic soil characteristics were identified similarly with the use of CLU as well as with FA. Therefore, based on the intersections of CLU and FA results, $D_{\mathrm{d}}, D_{\mathrm{s}}, M C C, P, B S, \mathrm{~N}_{\mathrm{t}}, \mathrm{C}_{\mathrm{FA}}$ and THS were classified as statistically close soil characteristics.

\section{Discriminant analysis}

Initial geographic division of beech forests

Frequencies of the included forest types as well as dominant forms of humus were clearly divided according to biogeographical subprovinces. However, in every bioregion, several distinctive soil units were found, or just one soil type. Sporadically detected units of geographic division of forests were not compared by DA with the other repeatedly detected characteristics. Significant differences between the soils within the eastern part of the Bohemian Massif 
(Hercynian sub-province) compared to those from the Outer Western Carpathians (West Carpathian sub-province) was not confirmed. However, DA indicated differences of soil conditions between mountain environment and lower locations. In highland to sub-montane locations, the prevailing associations were Luvisols, Haplic and Luvic Cambisol with uniform share of Leptomoder or Mullmoder. These lower associations appeared in 64\% of the stands assessed here. Associations of soil units and Mormoder covered only 14\% of the localities here. In montane locations, the prevailing associations were Podzols and Skeletic and Dystric Cambisols with Leptomoder to Humimor. By contrast, occurrence of soils with Mormoder was not detected. These higher associations appeared in $83 \%$ of the stands assessed here. The lower success of Mormoder indication was associated with its common occurrence with Leptomoder in Haplic and Luvic Cambisols in the Beskydský and Drahanský bioregions. At the same time, the dominant Leptomoder showed well-defined chemical properties, in contrast to the intermediate Mullmoder and Mormoder. The higher success of Mullmoder indication was due to its exclusive occurrence in Haplic Luvisol and stagnic soils within this study.

Distinguishability of soils with the use of selection of statistically close hydrostatic and physico-chemical properties depended strongly on the character of a horizon within the soil profile. Top-soil horizons were identified with $75 \%$ success, diagnostic horizons with $97 \%$ success. Specific differentiability of soil units from the individual soil horizons was assessed by comparison of the selected statistically close characteristics of repeatedly found Cambisols, Podzols and Luvisols. Cambisols were clearly determinable according to the properties of top-soil horizons. Besides, they were found in all bioregions of interest and in all geomorphological units included and so they could not be classified as a regionally-conditioned soil type by DA. Similarly, the properties of diagnostic horizons did not identify any of the compared groups of soils quite unambiguously. Sub-soil horizons, on the other hand, preserved the features necessary for clear identification of Podzols and Luvisols, trophically and texturally specific. The features of Podzols and Luvisols in top-soil as well as in diagnostic horizons were partially similar to Cambisols, but de facto, they were not close to them (Fig. 2).

Podzols were found only on the territory of the Beskydský bioregion in altitudes $>800 \mathrm{~m}$ a.s.l., Luvisols were detected in the Macošský and the Hranický bioregions in altitudes $<550 \mathrm{~m}$ a.s.l. Three different beech forest biotopes were determined on Podzols; on Luvisols there were mainly herb-rich beech forests in the Hranický bioregion and sporadically limestone beech forests in the Macošský bioregion. On Cambisols, on the other hand, herb-rich beech forests and montane sycamore beech forests jointly dominated over acidophilous beech forests.

The classified beech forest biotopes in the surveyed selection of forests seem mutually distinguishable with the probability $>50 \%$. Soil features of the studied beech stands in the Jeseníky Mts were very close to the features of soils from the Českomoravská Vrchovina Highlands; however, they were not distinguishable from the soils in the Západní Beskydy Mts. Reliability of distinguishability of the Západní Beskydy Mts. reached almost 96\% with regard to the other geomorphological units included. Soil conditions in the Brněnská vrchovina Highlands seemed equally similar to the Slovak-Moravian Carpathians and the foothills of the Západní Beskydy Mts (Table 3). However, only specific pairs of the compared biotopes reached relatively reliable mutual distinguishability. Soil conditions in limestone beech forests and in montane sycamore beech forests were reliably distinguishable. Herb-rich beech 

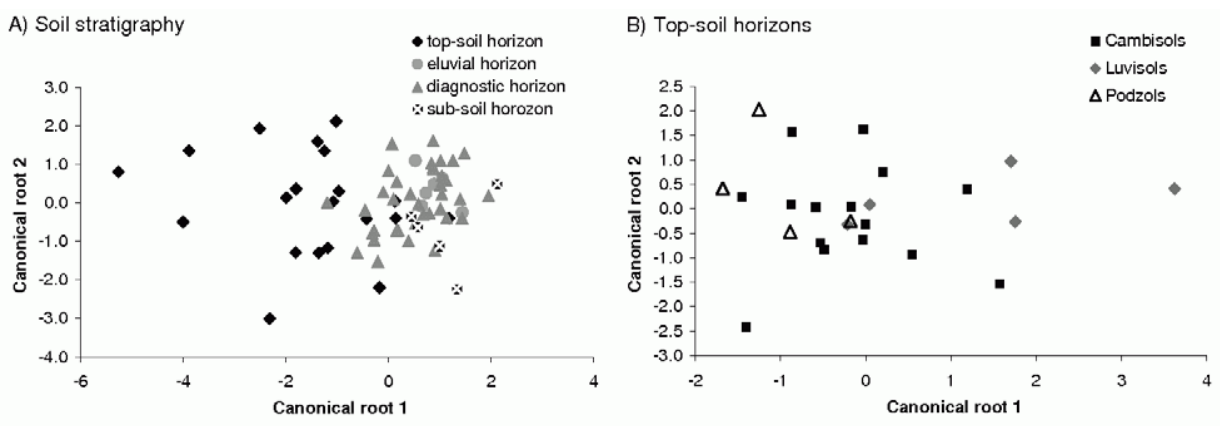

C) Diagnostic horizons

D) Sub-soil horizons
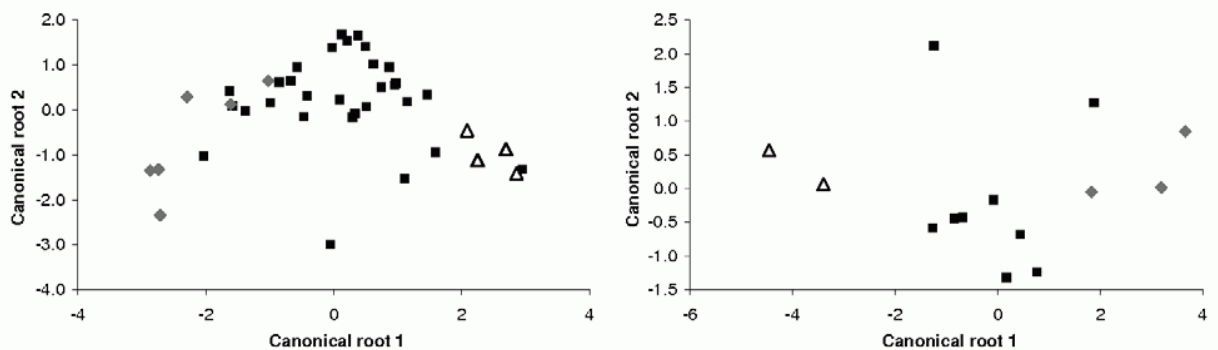

Fig. 2. Linear discriminant analysis of soil horizon properties dissimilarities among main soil groups at the selected beech forests.

forests and acidophilous beech forests were relatively well mutually distinguishable with the probability $>80 \%$. Distinguishability of soils in herb-rich beech forests from soils in montane sycamore beech forests and acidophilous beech forests corresponds well with their selection mainly in lower locations or in mountain locations. These differences in soil conditions of the selected beech forests were also reflected in connection with the prevailing altitudes of the compared bioregions. Higher reliability of correct identification of local soil specifics generally appeared in submontane bioregions. In highland and montane bioregions it was usually lower. The bioregions selected within the Westcarpathian subprovince were not only showing higher diversity of altitudinal conditions, but also higher average reliability of identification of local soil conditions (78\%). The higher reliability of correct distinguishability of local soil conditions was mainly due to the high levels of soil distinguishability in the Bělokarpatský, Hranický and Vsetínský bioregions. On the other hand, the selected soils within the Beskydský bioregion did not appear explicitly different compared to the Bohemian Massif regions or the other Carpathian regions, although they were typical with occurrence of Podzols. On the territory of the Hercynian subprovince, the average reliability of correct differentiation of the local soil conditions reached only $48 \%$. Soil conditions on the selected localities within the Drahanský and Macošský bioregions were close to the soils in the Hranický bioregion. Similarly, soils from the Jesenický bioregion resemble to a certain extent the soil conditions in the Beskydský bioregion (Fig. 3). 


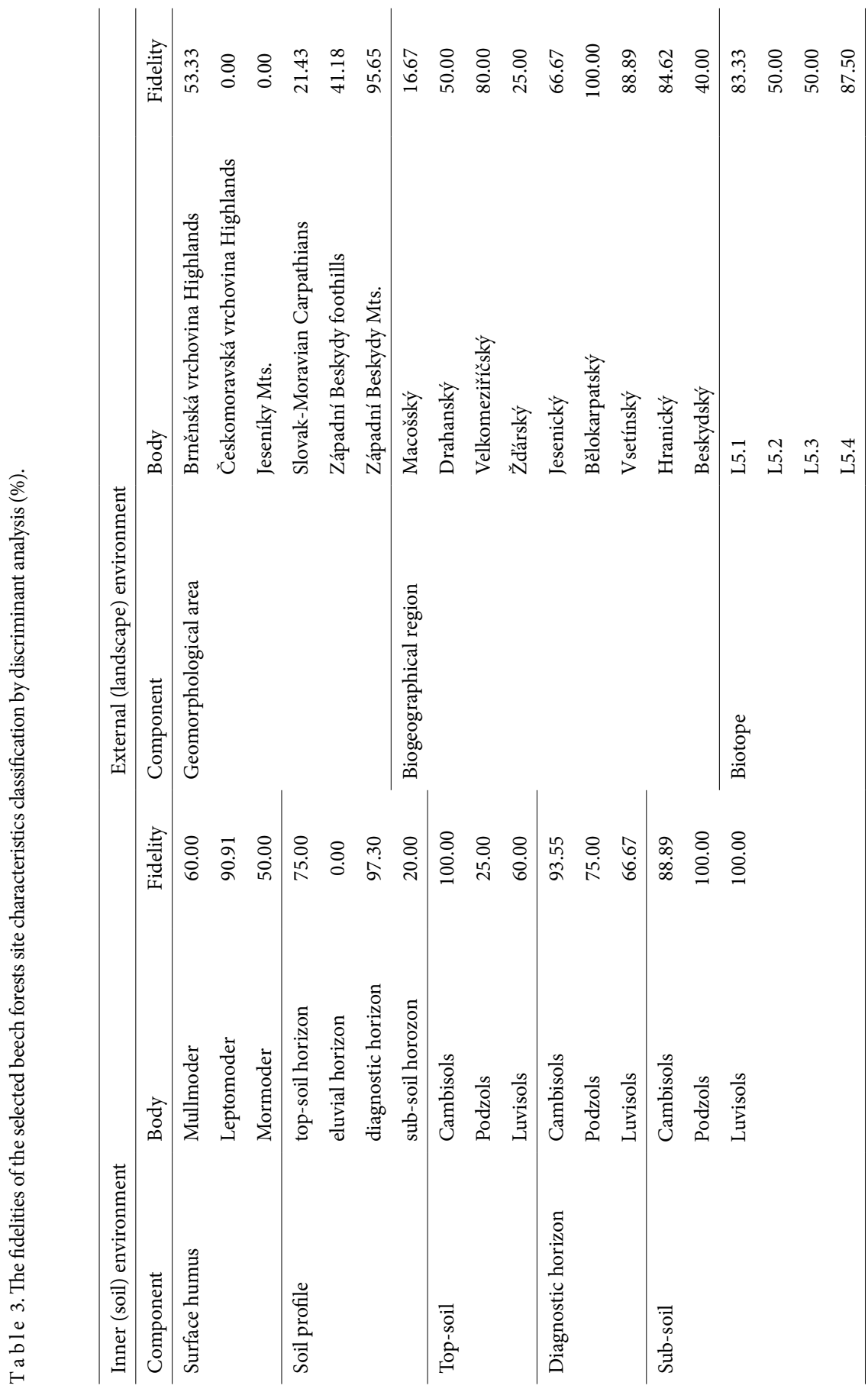


A) Geomorphological areas

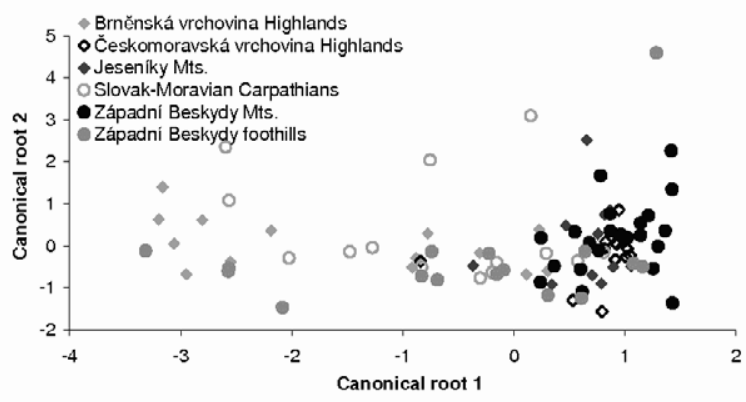

B) Biogeographical regions

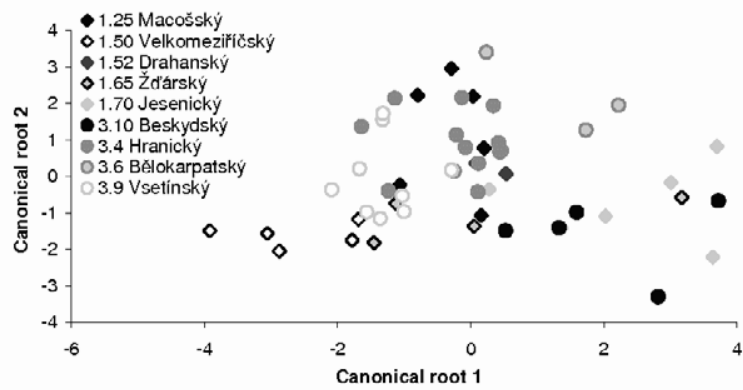

C) Natural beech forest biotopes

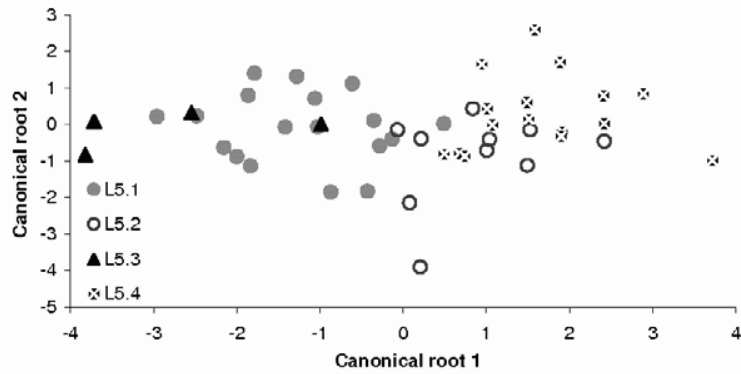

Fig. 3. Linear discriminant analysis of the selected beech forests geographical division dissimilarities.
Soil data form five relatively well distinguishable clusters of regionally different conditions for beech forest growth. The cluster of the Velkomeziríícský and Ždárský bioregions is formed of mutually close, but almost never overlapping soil conditions of beech forests, which are very well distinguishable from the Beskydy Mts and the Jeseníky Mts. Clearness of its differentiation is limited by the character of the data from the Ždárský bioregion, which are close both to the Vsetínský and the Macošský regions. The Bělokarpatský, Vsetínský and Hranický bioregions make up a cluster with very well distinguishable soils on average, corresponding to the soils sampled in the Macošský and Drahanský bioregion. However, soil conditions in the Macošský and Drahanský bioregions are not explicitly distinguishable from their surroundings. Although the clusters of the Jesenický and Beskydský bioregion together represent the mountain forest environment, due to the significant differences in the number of the soil pits included it is still necessary to respect mainly their natural positions within the Hercynian and Westcarpathian subprovinces and to assess them separately.

Soil-dependent biogeography of beech forests

Division of beech stands based on the analysis of soil conditions respected their pertinence to the Hercynian or Westcarpathian subprovince in general. The surveyed soil properties 
were mostly connected with highland or mountain forests. The set of typical specially-protected beech forest was divided into Hercynian montane beech forests, Hercynian highland beech forests, trans-Hercynian beech forests, Outer-Carpathian highland beech forests and Outer-Carpathian montane beech forests (Fig. 4). Within the studied area, both Hercynian and Carpathian montane beech forests included localities with abnormal occurrences of the monitored communities, different from the prevailing compared conditions.

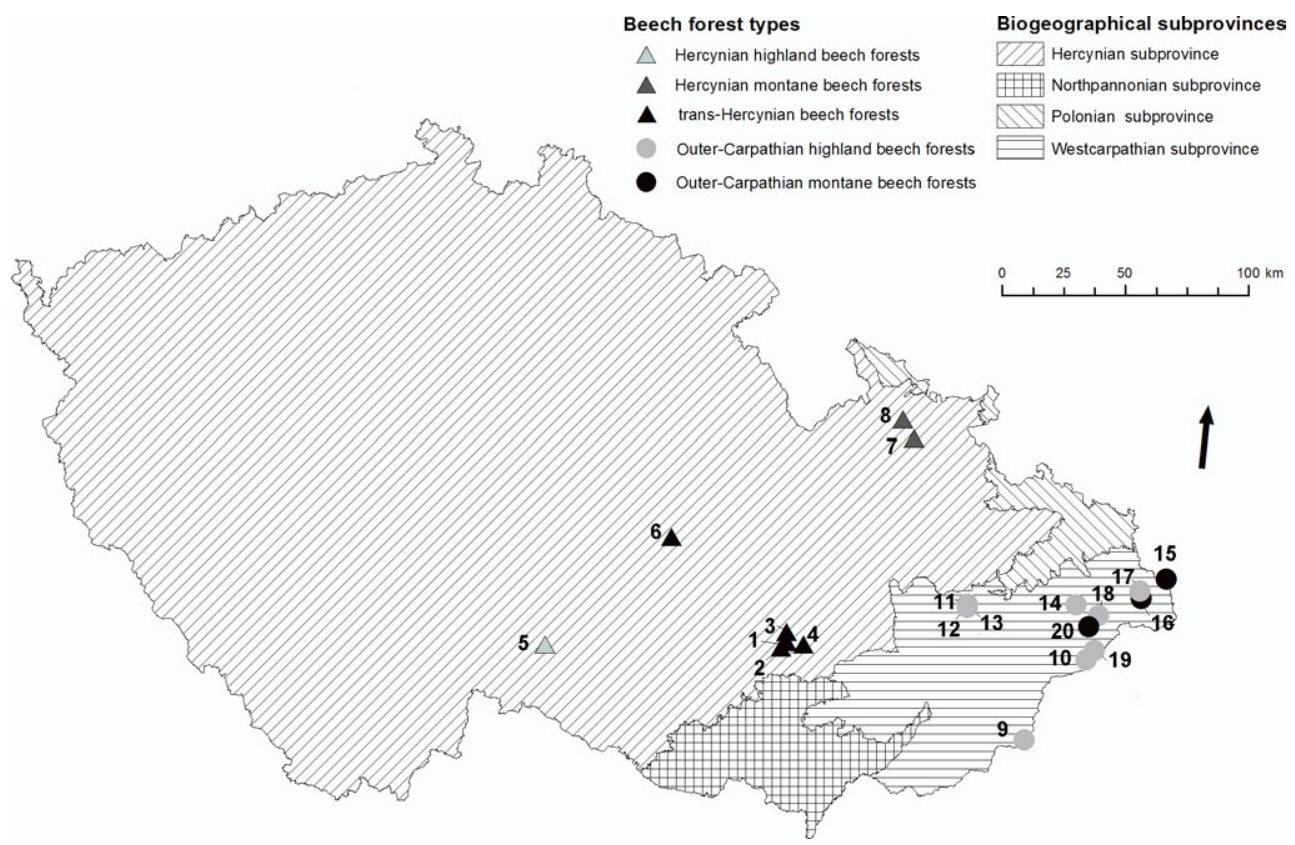

Fig. 4. Distribution of the natural beech forests classified by soil-dependent approach in the Czech Republic.

The cluster of the Velkomeziříčský and the Ždárský bioregions reached the average distinguishability of the soil conditions under beech forests of $53 \%$. It is represented by two stands of acidophilous beech forests only. This cluster groups the soil conditions of the Hercynian highland beech forests. As the material for assessment is not extensive and there is a marked difference between the two stands in the reliability of identification, it is also possible that only the surveyed stand within the Velkomeziř́čský bioregion belongs to the typical Hercynian beech forests. The soil features under the stand in the Ždárský bioregion indicate its similarity to both the Velkomeziříčský region and the Drahanský region. The cluster of the Drahanský and the Macošský bioregion shows the average distinguishability of the beech forest soil conditions of $33 \%$ only, therefore, together with the stand in the Ždárský bioregion, it potentially represents one of the transitions of soil conditions between the Hercynian and the Carpathian beech stands in the CR. On the territory of the Drahanský and the Macošský 
bioregions, it is represented by four stands of mainly limestone beech forests with transitions to acidophilous beech forests. It represents the soil conditions of the trans-Hercynian beech forests.

The cluster of the Bělokarpatský, Vsetínský and Hranický bioregions reached the average distinguishability of beech forest soil conditions of $91 \%$. It is represented by five stands with dominating herb-rich beech forests. Its soil conditions correspond to the Outer-Carpathian highland beech forests. The cluster of the Jesenický bioregion shows distinguishability of soil conditions of $67 \%$. It is represented by two stands of montane sycamore beech forests. Its soil conditions correspond to the Hercynian montane beech forests. The cluster of the Beskydský bioregion reached the average distinguishability of beech forest soil conditions of only $40 \%$, but it is represented by seven stands of mainly herb-rich beech forests with transition to montane sycamore-beech forests or even acidophilous beech forests. The conditions correspond to the Outer-Carpathian beech forests in general, but in relation to soil type they are closer to the Outer-Carpathian highland beech forests or to other Central-European montane forests. The selected stands on Podzols represent the typical montane beech forests and those on Cambisols are similar particularly to the Outer-Carpathian highland beech forests.

In the soil-depending division of beech forests within the given area, mainly the Hercynian montane, highland and Outer-Carpathian montane beech forests seem to be ecologically well distinguishable. On the other hand, trans-Hercynian and Outer-Carpathian highland beech stands differ from the surrounding types of beech forests by higher diversity of soils as well as biotopes. In all of the beech stands surveyed, bigger depths showed higher $B S$ and reversely lower content of organic matter. Hercynian montane beech forests corresponded to the L5.2 biotope with equal share of Skeletic and Dystric Cambisols. The values of $B S$ were $<16 \%$ here in general, the content of $\mathrm{C}_{\mathrm{FA}}$ was $0.3 \%$ and the content of THS $0.6 \%$ at the total porosity of diagnostic horizons $54 \%$ and $M C C 50 \%$. Hercynian highland beech forests were represented exclusively by acidophilous beech forests biotope L5.4 on Dystric Cambisols. The lowest values of $B S<10 \%$ and $\mathrm{N}_{\mathrm{t}} 0.04-0.10 \%$ were found here. Soil porosity did not reach $50 \%$ and similarly low was MCC with $27 \%$. Trans-Hercynian beech forests were mainly represented by basiphilous biotopes (L5.3) and also acid beech forests (L5.4) with the prevalence of either luvic soil types or Dystric Cambisols. Outer-Carpathian highland beech forests were represented mainly by herb-rich beech forests (L5.1) with relatively higher occurrence of Haplic Cambisols and relatively equal presence of Cambisols and Luvisols. On one hand, Outer-Carpathian montane beech forests were characterized by three biotopes, similar to the highland beech forests, but on the other hand by much lower diversity of soil types with clear prevalence of Entic and Haplic Podzols (Table 4).

Soil conditions in the trans-Hercynian beech forests were partially similar to the OuterCarpathian and also to Hercynian soils. Soils of the trans-Hercynian and Outer-Carpathian beech forests showed similar intervals of $D_{\mathrm{d}}, M C C, B S$ and $\mathrm{N}_{\mathrm{t}}$. By contrast, the contents of carbon compounds indicated similarity of the trans-Hercynian beech forests with the typical Hercynian as well as Carpathian beech forests. Volume weight of soils in both trans-Hercynian and Outer-Carpathian beech forests reached $1.4 \mathrm{~g} / \mathrm{cm}^{3}$ in the diagnostic horizon and 1.3 $\mathrm{g} / \mathrm{cm}^{3}$ in the sub-soil horizon. In the Hercynian beech forests, the average bulk density of the diagnostic soil horizon was $1.3 \mathrm{~g} / \mathrm{cm}^{3}$ and $1.5 \mathrm{~g} / \mathrm{cm}^{3}$ in the sub-soil horizon. MCC of soils 
$\mathrm{T} \mathrm{a} \mathrm{b} \mathrm{le} \mathrm{4.} \mathrm{The} \mathrm{composition} \mathrm{of} \mathrm{basic} \mathrm{ecological} \mathrm{units} \mathrm{of} \mathrm{soil-dependent} \mathrm{beech} \mathrm{forest} \mathrm{division} \mathrm{( \% ).}$

\begin{tabular}{|c|c|c|c|c|c|c|}
\hline $\begin{array}{l}\text { Ecological } \\
\text { component }\end{array}$ & Ecological unit & $\begin{array}{c}\text { Hecynian } \\
\text { montane } \\
\text { beech } \\
\text { forests }\end{array}$ & $\begin{array}{l}\text { Hercynian } \\
\text { highland } \\
\text { beech } \\
\text { forests }\end{array}$ & $\begin{array}{l}\text { trans-Hercyni- } \\
\text { an beech forests }\end{array}$ & $\begin{array}{c}\text { Outer- } \\
\text { Carpathian } \\
\text { highland } \\
\text { beech forests }\end{array}$ & $\begin{array}{c}\text { Outer- } \\
\text { Carpathian } \\
\text { montane } \\
\text { beech forests }\end{array}$ \\
\hline \multirow[t]{4}{*}{ Biotopes } & L5.1 & - & - & 20 & 78 & 33 \\
\hline & L5.2 & 100 & - & - & 11 & 33 \\
\hline & L5.3 & - & - & 40 & - & - \\
\hline & L5.4 & - & 100 & 40 & 11 & 33 \\
\hline \multirow[t]{11}{*}{ Soil types } & Calcaric Leptosol & - & - & 20 & - & - \\
\hline & Skeletic Cambisol & 50 & - & - & 11 & - \\
\hline & Dystric Cambisol & - & 100 & 20 & - & - \\
\hline & Haplic Cambisol & 50 & - & - & 33 & - \\
\hline & Luvic Cambisol & - & - & 40 & 22 & - \\
\hline & Stagnic Cambisol & - & - & - & 11 & - \\
\hline & Entic Podzol & - & - & - & - & 67 \\
\hline & Haplic Podzol & - & - & - & - & 33 \\
\hline & Ferric Luvisol & - & - & 20 & - & - \\
\hline & Haplic Luvisol & - & - & - & 11 & - \\
\hline & Stagni-albic Luvisol & - & - & - & 11 & - \\
\hline
\end{tabular}

in the trans-Hercynian and Outer-Carpathian beech forests was $>35 \%$; while in Hercynian beech forest soils, it was $>17 \%$. Soils of the Outer-Carpathian beech forests showed higher values of bulk density, porosity approx. $47 \%, M C C<42 \%$ and $B S<50 \%$. However, in the Carpathian montane beech forests, hydrostatic characteristic of soils were not determined. Soil base saturation values in the selected trans-Hercynian beech forests reached $>50 \%$, in the Outer-Carpathian highland beech forests soils, it was $>30 \%$ and in soils of the Outer-Carpathian montane beech forests, it was only $<10 \%$. The content of THS in the trans-Hercynian beech forests was generally $>0.3 \%$. The content of nitrogen in the diagnostic horizons of soils within the trans-Hercynian and Outer-Carpathian beech forests was mostly $>0.1 \%$, while in soils of the Hercynian beech forests, it reached $<0.1 \%$. As for nitrogen, its content in subsoil horizons of the trans-Hercynian and Outer-Carpathian beech forests generally did not exceed $0.1 \%$, but in sub-soil horizons of the Hercynian beech forests, it was mostly under $0.05 \%$ (Table 5).

\section{Discussion}

Soil environment affects both the vertical sequence of beech forest types and their regional division. Unequivocal determination of the real influence, that soil conditions have on the preference of a specific type of beech forest, depended mainly on the method of selection of suitable stands as well as on the geographic structure of the studied area. The method of selection of suitable stands is discussed (i) with regard to their representativeness and (ii) with regard to the significance of biogeographical boundaries within the studied area. 
$\mathrm{T} \mathrm{a}$ b l e 5 . Averages $\pm \mathrm{SD}$ of statistically similar soil properties at soil-dependent beech forest division on borderland of the Czech Massif and Outer Western Carpathians.

\begin{tabular}{llccccc}
\hline Horizon & Quantity & $\begin{array}{c}\text { Hecynian } \\
\text { montane } \\
\text { beech forests }\end{array}$ & $\begin{array}{c}\text { Hercynian } \\
\text { highland beech } \\
\text { forests }\end{array}$ & $\begin{array}{c}\text { trans-Hercynian } \\
\text { beech forests }\end{array}$ & $\begin{array}{c}\text { Outer- } \\
\text { Carpathian } \\
\text { highland beech } \\
\text { forests }\end{array}$ & $\begin{array}{c}\text { Outer- } \\
\text { Carpathian } \\
\text { montane } \\
\text { beech forests }\end{array}$ \\
\hline Diagnostic & $D_{\mathrm{d}}\left(\mathrm{g} / \mathrm{cm}^{3}\right)$ & $1.09 \pm 0.19$ & $1.33 \pm 0.11$ & $1.38 \pm 0.23$ & $1.40 \pm 0.22$ & - \\
& $D_{\mathrm{s}}\left(\mathrm{g} / \mathrm{cm}^{3}\right)$ & $2.58 \pm 0.15$ & $2.57 \pm 0.03$ & $2.52 \pm 0.07$ & $2.58 \pm 0.07$ & - \\
& $M C C(\%)$ & $49.64 \pm 9.72$ & $26.67 \pm 2.64$ & $36.61 \pm 3.40$ & $38.44 \pm 5.26$ & - \\
& $P(\%)$ & $54.18 \pm 5.74$ & $48.30 \pm 3.97$ & $45.72 \pm 7.51$ & $45.99 \pm 7.58$ & - \\
& $B S(\%)$ & $15.72 \pm 7.57$ & $9.11 \pm 0.22$ & $50.55 \pm 31.49$ & $29.98 \pm 21.97$ & $9.73 \pm 3.19$ \\
& $N_{\mathrm{t}}(\%)$ & $0.14 \pm 0.09$ & $0.09 \pm 0.03$ & $0.12 \pm 0.04$ & $0.13 \pm 0.06$ & $0.20 \pm 0.04$ \\
& $C_{\mathrm{FA}}(\%)$ & $0.29 \pm 0.14$ & $0.25 \pm 0.06$ & $0.25 \pm 0.14$ & $0.24 \pm 0.23$ & $0.68 \pm 0.10$ \\
& $T H S(\%)$ & $0.58 \pm 0.13$ & $0.35 \pm 0.09$ & $0.36 \pm 0.27$ & $0.37 \pm 0.35$ & $0.96 \pm 0.13$ \\
\hline Sub-soil & $D_{\mathrm{d}}\left(\mathrm{g} / \mathrm{cm}^{3}\right)$ & $0.68 \pm 0.00$ & $1.53 \pm 0.00$ & $1.26 \pm 0.00$ & $1.28 \pm 0.00$ & - \\
& $D_{\mathrm{s}}\left(\mathrm{g} / \mathrm{cm}^{3}\right)$ & $2.39 \pm 0.00$ & $2.67 \pm 0.00$ & $2.62 \pm 0.01$ & $2.44 \pm 0.02$ & - \\
& $M C C(\%)$ & $68.36 \pm 7.42$ & $17.17 \pm 1.03$ & $35.50 \pm 3.58$ & $41.05 \pm 4.07$ & - \\
& $P(\%)$ & $71.52 \pm 8.14$ & $42.68 \pm 3.01$ & $51.97 \pm 7.74$ & $47.45 \pm 5.12$ & - \\
& $B S(\%)$ & $27.47 \pm 9.75$ & $10.37 \pm 0.00$ & $66.58 \pm 38.64$ & $46.47 \pm 35.53$ & $9.78 \pm 0.60$ \\
& $N_{\mathrm{t}}(\%)$ & $0.08 \pm 0.03$ & $0.04 \pm 0.00$ & $0.10 \pm 0.03$ & $0.08 \pm 0.03$ & $0.11 \pm 0.01$ \\
$C_{\mathrm{FA}}(\%)$ & $0.14 \pm 0.02$ & $0.13 \pm 0.00$ & $0.27 \pm 0.14$ & $0.15 \pm 0.12$ & $0.45 \pm 0.07$ \\
$T H S(\%)$ & $0.26 \pm 0.08$ & $0.16 \pm 0.00$ & $0.39 \pm 0.20$ & $0.23 \pm 0.19$ & $0.57 \pm 0.08$ \\
\hline
\end{tabular}

Regarding the geographical structure of the area, the topics of discussion include (i) the importance of selection of statistically close soil characteristics, (ii) the role of soil conditions in ecological biogeography, and (iii) the suggested hypothesis of soil-depending division of beech forests.

\section{Selection of suitable beech stands}

Classification of soil conditions in beech forests was affected not only by methodological requirements related to the state of the stands, but also by their selection mainly in the upland locations at the eastern edge of the Bohemian Massif and the Outer Western Carpathians. Selection of typical natural beech forests was performed with respect to the approaches of geobiocoenological ecosystem classification as well as the level of preservation of representative natural communities in intensively utilized cultural landscapes (Buček et al., 2007). On average, representation of European beech in Carpathian parts of the CR is higher than in the area of interest within the Bohemian Massif and so the preference of Carpathian regions in the performed survey was due to the higher occurrence of the required biotopes.

In the borderland between the Bohemian Massif and the Outer Western Carpathians, there are lowlands with conditions mainly suited to azonal vegetation, where the Hercynian and Carpathian beech forests mostly are not in direct contact. This boundary determines the course of the borders of Hercynian, Northpannonian, Westcarpathian and Polonian biogeographical sub-provinces within the territory of the CR. 
Hercynian and Carpathian beech forests meet peripherally on the territory of the Polonian sub-province (Horáček et al., 2011) and also they appear near each other on the territory of the Ždánický Les Mts (in Ždánicko-Litenčický bioregion) and the Drahanská Vrchovina Highland (Drahanský bioregion) (cf. Culek, 1996), where the conditions of occurrence of specific trans-Hercynian beech forests, were determined.

Contact of the beech forests on the border between the Hercynian, Polonian and Westcarpathian subprovince is conditioned both by the prevalence of flat upland relief and the prevailing Planosols, as Cambisols, dominant in other regions, appear only in higher locations of the area of interest. For the purpose of the beech geobiocoenoses survey, a set of north-south transects was used, where the close-to-nature stands (with the beech occurrence $>50 \%$ and more than 60 years old) were sampled.

Soil conditions in this part of the CR indicated potential occurrence of Polonian geobiocoenoses up to the foothills of the Moravskoslezské Beskydy Mts (Horáček et al., 2011). On one hand, the design of serial transects captured all sufficiently compact beech forests on the surveyed biogeographical border, but on the other hand, unlike the survey of beech forests with special protection status, its purpose was not to differentiate between natural and close-to-nature forests. From the selection of statistically close soil characteristics, the base cation content, content of exchangeable and bound forms of aluminium and BS were the most significant for the analysis of relations in soil bodies as well as for analysis of the transitions of soil conditions between the Polonian and the West Carpathian sub-province. However, while the classification of beech forests on the border between the Polonian and the West Carpathian sub-province was based on combination of CLU, PCA and VCA of soil and phytocoenological data, only DA of soil characteristics was used in the survey of beech forests with special protection status. We assumed that soil conditions form the most important component of the permanently-acting factors, while the reliability of phyto-indication of the herbal undergrowth is subject to profound changes related to the structure, canopy and naturalness of the parent stand (Viewegh, 2002). Nevertheless, it cannot be excluded that incorporation of phyto-indication would enable higher accuracy of classification of soil conditions in beech forests, and it can be assumed that it would contribute also to the estimates of transition gradients between the typically Hercynian, trans-Hercynian and Carpathian beech forests.

The Outer Carpathian lowlands formed an important migration corridor during the Quaternary and were significant also for European beech expansion into the central Europe. Glacial refugia of central European beech forests occurred in lowlands of the Alps. From the refugium of the Eastern Alps (Slovenia-Istria), beech spread to south Moravia (the border of the present Northpannonian, Hercynian and Westcarpathian sub-provinces), from which it expanded further north (Magri et al., 2006). Together with south Moravia, the Šumava Mts and the Bohemian Forest Mts also contributed as centres of the European beech distribution range during the last two glacial/interglacial cycles, as indicated from where the natural vegetation of central Europe originated (Svobodová et al., 2001).

The unique diversity of soil-forming substrates on the border of the Bohemian Massif and the Outer Western Carpathians affected the development of forests here. Regional differences in the water-holding capacity could potentially have been the factor conditioning the devel- 
opment of root systems in tree species, which led to permanent differentiation of competition between forest communities. The present site conditions here are typical with alteration of terrain fractures and peneplains and with loess soils. The material of local loesses and loess soils came mainly from the Brno Massif granodiorites (Brněnský bioregion). Texture of the loess soils in the eastern parts of the Bohemian Massif generally shows similarities to the weathered clay-stones and marls in the Outer Western Carpathians (Lisá, Uher, 2006; Fitzsimmons et al., 2012). Although these similarities explain the similar soil properties in the Outer-Carpathian and the trans-Hercynian beech forests, the ability to discriminate between the regionally specific beech forest types here is supported by the differences of forest resistance to stress (Purdon et al., 2004; Cienciala et al., 2006). From the properties of soil, diversity of tree species resistance to stress depends mainly on $B S$ and its relation to humic substances, which, mainly on the localities with trans-Hercynian beech forests, reached the highest values on average and also high $S D$.

\section{Selection of soil characteristics}

The performed analyses of beech forest division were always based on the selection of soil characteristics that exhibited closer mutual relations than to the other characteristics. During soil characteristic selection, the best interpretable similarities were found between the results of FA of the original values and robust CLU, despite the fact that FA is sensitive to fulfilment of the assumption of normal data distribution and in most of the compared characteristics, data normality was markedly violated.

Nevertheless, the source form of the data and their z-transformations showed more similarities than with the normalized data. In central Europe, similar results of relations between soil hydrostatic characteristics, THS, $\mathrm{C}_{\mathrm{FA}}$ and $\mathrm{N}_{\mathrm{t}}$ were found not only in beech forests (Allison, 1973; Finzi et al., 1998; Patzel, Ponge, 2001), but also in oak (Grunda, 1993), pine (Borken et al., 2002) and spruce forests (Berger, Hager, 2000).

Results of FA and from the literature agree on the finding that humic substances decrease the values of $D_{\text {w }} D_{\mathrm{d}}$ and $D_{\mathrm{s}}$ and, on the other hand, increase MCC and BS. Sufficient content of humic substances improves the growing environment of forest tree species; therefore it is a potential indicator of efficiency of forest community competitiveness. Correct selection of only those soil properties that directly interact with plants suppresses the side effects of the growing environment and also documents the specific differences in soils caused by the plant community. DA indicated that the differences between these soil characteristics divide the surveyed set of beech stands into regional clusters.

The presumptions on the relations between the surveyed forest stands and soil were preserved also in the character of distribution of humus forms and soil types. The joint effect of a beech stand and the external growing conditions was reflected in the sequence from the dominance of Leptomoder on Cambisols and Luvisols to the dominance of Humimor on Podzols. Poor soil environment leads to incomplete formation of humic polymers and accumulation of raw humus. Nevertheless, in beech stands on Podzols, we found exclusively Humimor with dominant humification subhorizon and not nominal Hemimor with equal share of subhorizons of raw organic matter and humified matter. 
In beech forests, the differences between the sub-soil horizons of Cambisols, Luvisols and Podzols asserted themselves. The dividing line between the conditions for the occurrence of highland and of montane forests probably lies in the altitude of $800 \mathrm{~m}$ a.s.l. In lower locations, beech forests are relatively more frequently found on stagnic soils, while montane beech forests develop more often on Entic Podzols and Haplic Podzols. Still, this altitudeconditioned occurrence of soil types is not necessarily typical for either Hercynian or Carpathian beech forests.

The relations between beech and soil on the present border between the Northpannonian, Hercynian and West Carpathian sub-provinces may potentially be older than on the other areas of the Hercynian or the West Carpathian sub-provinces. Statistical indication of soil conditions in the trans-Hercynian beech forests may point to more developed soil relations than in the surrounding highland or montane beech forests. Occurrence of Calcaric Leptosols indicates poorly developed soils with high buffering capacity; on the other hand, occurrence of Dystric Cambisols or Ferric Luvisols indicates the presence of substrate predisposed soils, or soil with advanced development (White, 1987; Driessen et al., 2001).

One of the effects of the more developed soil relations in the trans-Hercynian beech forests compared to the surrounding highland beech forests may be the higher values of soil $M C C$ and $P$. Although the $D_{\mathrm{d}}$ and $D_{\mathrm{s}}$ intervals indicated similarities in the compared soils, the contents of THS in sub-soils revealed deeper translocation of organic substances, connected also to higher values of MCC. In the trans-Hercynian beech forests, efficiency of soil links could be manifested in better water-holding capacity; thanks to deeper penetration of humic substances.

\section{Geographical structure of the surveyed area}

Distribution of soil types did not show a clearly documented relation to regional differences in the character of the surveyed beech forests. However, it corresponded to the altitudinal division of the natural biotopes. Classification of beech biotopes on the territory of the CR does not work with regional varieties. Nevertheless, the observed frequencies of soil units in the individual biotopes indicated that an unrepeatable sequence of local types of beech forests may occur on the surveyed border between the Bohemian Massif and the Outer Western Carpathians.

On one hand, the general character of the distribution of soil units in different natural biotopes of beech forests is supported by the observed extensive representation of Cambisols, but on the other hand, the regionally-specific character of soil unit distribution is documented by the occurrence of Podzols. The occurrences of Podzols on the territory of the Outer Western Carpathians probably explains the reliability of distinguishability of the Western Beskids, where the use of statistically close soil characteristics reached almost $96 \%$ in relation to the other geomorphological units included.

The most typical soils of beech forests are Cambisols. They were found in all of the surveyed geomorphological regions and bioregions, therefore, if only stands on Cambisols are selected, regional specifications of the studied beech forests are indistinctive.

The features of top-soil horizons in Cambisols were the best to indicate the impacts of a 
plant community on soil conditions. Although diagnostic horizons remain the keystone of soil identification, they did not identify any of the compared groups of soils unambiguously. Likewise, although the sub-soil horizons do not represent a suitable environment for identification of differences within soil bodies, they had preserved the features necessary for clear differentiation of the trophically and texturally specific Podzols and Luvisols. The TSH and MCC intervals in sub-soils also affected indication of the regional variants of beech forests, which were based mainly on the deviations from the prevailing soil conditions.

Occurrence of Hercynian, Carpathian and transient beech forests was predicted from the variability between the selected humic, physico-chemical and hydrostatic properties of soils. Features of sub-soils may indicate even the potential occurrence of beech stands, regardless of the current vegetation. Five clusters of local beech forest types were distinguished according to DA, however, due to their uneven distribution, the more simple division into three groups is better demonstrative. Uneven distribution limits representativeness of the indicated types; therefore, it is not clearly documented whether their occurrence is limited to one locality or whether they belong to some widely dispersed ecosystem.

Differences within beech forest groups are mainly affected by occurrence of soil types. Nevertheless, based on the stands from the Drahanský and Macošský bioregion, we distinguished the trans-Hercynian beech forests as the main local type of beech forests in the borderland between the Bohemian Massif and the Outer Western Carpathians.

\section{Conclusion}

On the sites of dominant beech forests, soil properties evidently represent a more significant set of ecological indicators than herbal undergrowth. Biogeographical classification of the studied beech forests was affected by soil environment in a vertical direction, from higher occurrence of Luvisols to higher occurrence of Podzols, and in a horizontal direction, by the ranges of volume weight and specific weight values, $M C C, B S, \mathrm{~N}_{\mathrm{t}}$ and $\mathrm{C}_{\mathrm{FA}}$. The ranges of the selected statistically close soil characteristics indicated trans-Hercynian beech forests on the transition between the Hercynian and Carpathian forests. In the montane conditions, the lower BS together with higher content of $\mathrm{C}_{\mathrm{FA}}$, mainly in Podzols, caused differences between the montane beech forests and the beech forests in altitudes $<800 \mathrm{~m}$ a.s.l. regardless of the region of occurrence.

In the highland locations on the eastern edge of the Bohemian Massif, some sites show soil conditions more similar to the Carpathian than to Hercynian highlands. Trans-Hercynian beech forests are potentially present on sites with deeper penetration of humic substances on soils with higher content of silt and clay particles. Their sites are close to South-Moravian refugia of Central-European beech forests, hence they are also important for more detailed description of the course of beech succession in the Holocene as well as for description of the ecological stability of natural forests in the changing external environment.

Vegetation classification systems that fail to sufficiently reflect the regional differences in ecology may help to generalize data; however their orientation to regional specifications in forest ecology requires simultaneous assessment of the local site conditions. More effective classification of beech forests in the Hercynian and the West Carpathian sub-provinces 
depends on the understanding of the role of soil in vegetation classification as well as on determination of regional forest types.

\section{Acknowledgements}

The authors gratefully acknowledge the support by the Operational Program Education for Competitiveness - European Social Fund (project CZ.1.07/2.3.00/20.0170 of the Ministry of Education, Youth and Sports of the Czech Republic) and by the frameworks TA 02020867 of the Technology Agency of the Czech Republic and IGA 84/2013 of the Training Forest Enterprise Masaryk Forest Křtiny.

\section{References}

Allison, F.E. (1973). Soil organic matter and its role in crop production. Amsterdam, London: Elsevier.

Barbati, A., Corona, P. \& Marchetti M. (2007). European forest types. Categories and types for sustainable forest management reporting and policy. Copenhagen, Luxembourg: European Environment Agency.

Berger, T.W. \& Hager H. (2000). Physical top soil properties in pure stands of Norway spruce (Picea abies) and mixed species stands in Austria. For. Ecol. Manag., 136, 159-172. DOI: 10.1016/S0378-1127(99)00286-8.

Borken, W., Xu, Y.-J., Davidson, E.A. \& Beese F. (2002). Site and temporal variation of soil respiration in European beech, Norway spruce, and Scots pine forests. Global Change Biology, 8(12), 1205-1216. DOI: 10.1046/j.13652486.2002.00547.x.

Box, G.E.P. \& Cox D.R. (1964). An analysis of transformations. Journal of Royal Statistical Society Series B, 26, 211-246. URL: http://www.jstor.org/stable/2984418.

Buček, A., Maděra, P. \& Úřadníček L. (2007). Ecological network creation in the Czech Republic. Journal of Landscape Ecology, 1: 12-24.

Casper, B.B. \& Jackson R.B. (1997). Plant competition underground. Ann. Rev. Ecol. Syst., 28, 545-570. DOI: 10.1146/annurev.ecolsys.28.1.545.

Christensen, M., Hahn, K., Mountford, E. P., Ódor, P., Standová, T., Rozenbergar, D., Diaci, J., Wijdeven, S., Meyer, P., Winter, S. \& Vrška T. (2005). Dead wood in European beech (Fagus sylvatica) forest reserves. For. Ecol. Manag., 210, 267-282. DOI: 10.1016/j.foreco.2005.02.032.

Cienciala, E., Exnerová, Z., Macků, J. \& Henžlík V. (2006). Forest topsoil organic carbon content in Southwest Bohemia region. J. For. Sci., 52, 387-398.

Chytrý, M. (2012). Vegetation of the Czech Republic: diversity, ecology, history and dynamics. Preslia, 84, 427-504.

Chytrý, M., Kučera, T. \& Kočí M. (Eds.) (2001). Katalog biotopů České republiky. Praha: AOPK ČR.

Craine, J.M. (2007). Plant strategy theories: replies to Grime and Tilman. J. Ecol., 95, 235-240. DOI: 10.1111/j.13652745.2007.01212.x.

Culek, M. (Ed.) (1996). Biogeografické členění České republiky. Praha: Enigma.

Davi, H., Dufrêne, E., Granier, A., Le Dantec, V., Barbaroux, C., Francois, C. \& Bréda N. (2005). Modelling carbon and water cycles in a beech forest. Part II: Validation of the main processes form organ to stand scale. Ecol. Model., 185, 387-407. DOI: 10.1016/j.ecolmodel.2005.01.003.

Demek, J. (1987). Hory a nížiny. Zeměpisný lexikon ČSR. Praha: Academia.

Diaci, J. \& Rozenbergar D. (2003). Interactions of light, soil properties and regeneration in the Slovenian Dinaric Alps: Patterns in virgin and managed forests. In F. Hamor \& B. Commarmot (Eds.), Natural forests in the temperate zone of Europe - values and utilization (pp. 58-59). Mukachevo, Rakhiv, Birmensdorf: Carpathian Biosphere Reserve, Swiss Federal Research Institute.

Driessen, P., Deckers, J. \& Nachtergaele F. (Eds.) (2001). Lecture notes on the major soils of the world. Rome: FAO.

Ellenberg, H. (1996). Vegetation Mitteleuropas mit den Alpen in ökologischer und historischer Sicht. Stuttgart: Verlag Eugen Ulmer GmbH.

Finzi, A.C., Canham, C.D. \& van Breemen N. (1998). Canopy tree soil interactions within temperate forests: Species effects on pH and cations. Ecol. Appl., 8, 447-454. DOI: 10.1890/1051-0761(1998)008[0447:CTSIWT]2.0.CO;2

Fitzsimmons, K.E., Marković, S.B. \& Hambach U. (2012). Pleistocene environmental dynamics recorded in the loess of the middle and lower Danube basin. Quaternary Science Reviews, 41, 104-118. DOI: 10.1016/j.quascirev.2012.03.002.

Gaston, K.J. \& Spicer J.I. (2004). Biodiversity: an introduction. Oxford: Blackwell Publishing. 
Gégout, J.-C. \& Križová E. (2003). Comparison of indicator values of forest understory plant species in Western Carpathians (Slovakia) and Vosges Mountains (France). For. Ecol. Manag., 182, 1-11. DOI: 10.1016/S03781127(03)00068-9.

Godefroid, S., Massant, W. \& Koedam N. (2005). Variation in the herb species response and the humus quality across a 200-year chronosequence of beech and oak plantations in Belgium. Ecography, 28, 223-235. DOI: 10.1111/j.0906-7590.2005.03877.x.

Gömöry, D., Hynek, V. \& Paule V. (1998). Original article Delineation of seed zones for European beech (Fagus sylvatica L.) in the Czech Republic based on isozyme gene markers. Ann. For. Sci., 55, 425-436. DOI: $10.1051 /$ forest:19980403.

Green, R.N., Trowbridge, R.L. \& Klinka K. (1993). Towards a taxonomic classification of humus forms. For. Sci. (Monograph 29), 39(Suppl. 1), a0001-z0002.

Grunda, B. (1993). Objemová hmotnost půdy v půdní mikrobiologii. Lesnictví-Forestry, 41, 38-41.

Horáček, M., Holuša, O. \& Samec P. (2011). Line of border of the Polonic and Westcarpathian biogeographical subprovinces in the Czech Republic. Acta Musei Beskidensis, 3, 17-31.

Houba, V.G.J., van der Lee, J.J., Novozamsky, I. \& Walinga I. (1989). Soil analysis procedures. Soil and plant analysis, Part 5. Wageningen: Wageningen Agricultural University.

Kaplan, Z. (2012). Flora and phytogeography of the Czech Republic. Preslia, 84, 505-573.

Knollová, I. \& Chytrý M. (2004). Oak-hornbeam forests of the Czech Republic: geographical and ecological approaches to vegetation classification. Preslia, 76, 291-311.

Kučera, A., Rejšek, K., Dundek, P., Marosz, K., Samec, P. \& Sýkora J. (2011). Specification of the beechwood soil environment based on chosen soil properties, aiming at the Faseta paupera habitat. J. For. Sci., 57, 185-191.

Lisá, L. \& Uher P. (2006). Provenance of Würmian loess and loess-like sediments of Moravia and Silesia (Czech Republic): a study of zircon typology and cathodoluminiscence. Geol. Carpathica, 57, 397-403.

Magri, D., Vendramin, G.G., Comps, B., Dupanloup, I., Geburek, T., Gömöry, D., Latałowa, M., Litt, T., Paule, L., Roure, J.M., Tantau, I., van der Knaap, W.O., Petit, R.J. \& de Beaulieu J.-L. (2006). A new scenario for the Quarternary history of European beech populations: palaeobotanical evidence and genetic consequences. New Phytol., 171, 199-221. DOI: 10.1111/j.1469-8137.2006.01740.x.

Ngao, J., Epron, D., Brechet, C. \& Granier A. (2005). Estimating the contribution of leaf litter decomposition to soil $\mathrm{CO}_{2}$ efflux in a beech forest using ${ }^{13} \mathrm{C}$-depleted litter. Global Change Biology, 11(10), 1768-1776. DOI: $10.1111 /$ j.1365-2486.2004.01014.x.

Patzel, N. \& Ponge J.-F. (2001). The heterogeneity of humus components in a virgin beech forests. Eur. J. Soil Biol., 37, 117-124. DOI: 10.1016/S1164-5563(01)01076-7.

Pott, R. (2000). Palaeoclimate and vegetation - long-term vegetation dynamics in central Europe with particular reference to beech. Phytocoenologia, 30, 285-333. DOI: 10.1127/phyto/30/2000/285.

Purdon, M., Cienciala, E., Metelka, V., Beranová, J., Hunová, I. \& Černý M. (2004). Regional variation in forest health under long-term air pollution mitigated by lithological conditions. For. Ecol. Manag., 195, 355-371. DOI: 10.1016/j.foreco.2004.02.039.

Qian, H. \& Ricklefs R.E. (2004). Geographical distribution and ecological coservatism of disjunct genera of vascular plants in eastern Asia and eastern North America. J. Ecol., 92, 253-265. DOI: 10.1111/j.0022-0477.2004.00868.x.

Rand, W.M. (1971). Objective criteria for the evaluation of clustering methods. Journal of the American Statistical Association, 66, 846-850. DOI: 10.1080/01621459.1971.10482356.

Seynave, I., Gégout, J.-G., Hervé, J.-C., Dhôte, J.-F., 2008: Is the spatial distribution of European beech (Fagus sylvatica L.) limited by its potential height growth? Journal of Biogeography 35: 1851-1862. DOI: 10.1111/j.13652699.2008.01930.x.

Schmid, I. (2002). The influence of soil type and interspecific competition of the fine root system of Norway spruce and European beech. Basic and Applied Ecology, 3, 339-346. DOI: 10.1078/1439-1791-00116.

Simon, J. (Ed.) (2003). Monitorovací plochy soustavy NATURA 2000 v České republice (1. část). Brno: Paido.

Simon, J. (2004). Management strategies on territories with special status of protection in the Czech Republic. J. For. Sci., 50, 510-513.

Simon, J. (Ed.) (2010). Strategie managementu lesních území se zvláštním statutem ochrany. Obecná část I. Kostelec nad Černými lesy: Lesnická práce.

Sugiero, D., Jaszczak, R., Rączka, G., Strzelinski, P., Węgiel, A. \& Wierzbicka A. (2009). Species composition in low mountain beech (Fagus sylvatica) stands in the Bieszczady National Park under the global warming. J. For. Sci., 55, 244-250. 
Svobodová, H., Reille, M. \& Goeury C. (2001). Past vegetation dynamics of Vltavský luh, upper Vltava river valley in th Šumava mountains. Czech Republic. Veg. Hist. Archaebot., 10, 185-199. DOI: 10.1007/PL00006930.

Tan, K.H. (2003). Humic matter in soil and the environment: principles and controversies. New York: Marcel Dekker Inc.

USDA-NRSC (1996). Soil survey laboratory methods manual. Washington.

van der Poel, P.W. (1976). Influence of environmental factors in the growth of the beech. Catena, 3, 203-214. DOI: 10.1016/0341-8162(76)90010-2.

Vavríćček, D., Šimková, P., Samec, P. \& Formánek P. (2006). Soil aspects of forest site revitalization after windrow cultivation by heavy mechanization on the Krušné hory Mts. Plateau. J. For. Sci., 52, 1-12.

Verdú, M., Dávila, P., García-Fayos, P., Flores-Hernandes, N. \& Valiente-Banuet A. (2003). 'Convergent' traits of Mediterranean woody plants belong to pre-mediterranean linkage. Biol. J. Linn. Soc., 78, 415-427. DOI: 10.1046/j.1095-8312.2003.00160.x.

Viewegh, J. (2002). South-Moravian floodplain forest herb vegetation in the period 1978-1997. J. For. Sci., 48, 88-92.

Voženílek, V. (2000). Regionální členění reliéfu ČR, mapa 1: 1250 000. Olomouc: Katedra geografie UP Olomouc.

Walkley, A. \& Black I.A. (1934). An examination of the Degtjareff method for determinating soil organic matter and a proposed modification of the chromic acid titration method. Soil Sci., 37, 29-38.

Wheeler, P.A. \& Ward R.B. (1998). The non-toxic farming handbook. Austin: Acres U.S.A.

White, R.E. (1987). Introduction to the principles and practice of soil science. Oxford: Blackwell Scientific Publications.

Zar, J. (1994). Biostatistical analysis. New Jersey: Prentice Hall Int.

Zinke, P.J. (1962). The pattern of influence of individual forest trees on soil properties. Ecology, 43, 130-133. DOI: $10.2307 / 1932049$. 